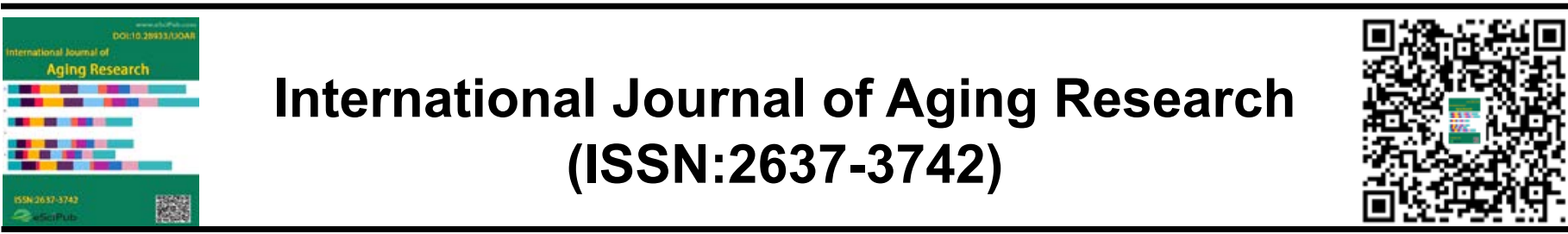

\title{
Depression and suicidal ideation in institutionalized elderly in Recife
}

Evandro Valentim da Silva; Carla Andrea de Moura; Carolina Silva de Aleluia; José Marcio Nogueira da Silva; Fálba Bernadete Ramos dos Anjos; Eliane Helena Alvim de Sousa

\section{ABSTRACT}

This study aimed to analyze the disorders of depression and ${ }^{*}$ Correspondence to Author: suicidal ideation in a population of institutionalized elderly in the Evandro Valentim da Silva city of Recife - PE. To measure the phenomena under study two standardized scales were adopted, the BECK SCALE FOR Suicide Ideation (BSI) and the Geriatric Depression Scale (GDS / GDS). The collected data were entered into a database, and staHow to cite this article: tistical procedures performed using the Statistical Package for Evandro Valentim da Silva; Carla Social Sciences (SPSS) version 13.0 for Windows. After analysis Andrea de Moura; Carolina Silva of the data was possible to show that with the EDG, $48 \%$ of the de Aleluia; José Marcio Nogueira interviewed elderly population is with some degree of depresda Silva; Fálba Bernadete Ramos sion. It was observed higher scores on the BSI scale for women. Among the elderly depression affects more the age less than 80 years, suicidal ideation was little evident in the population studied, being more related to female dos Anjos; Eliane Helena Alvim de Sousa. Depression and suicidal ideation in institutionalized elderly in Recife. International Journal of Aging Research, 2019, 2:36

Keywords: Geriatric Depression. suicidal ideation in the elderly. depression in institutionalized elderly

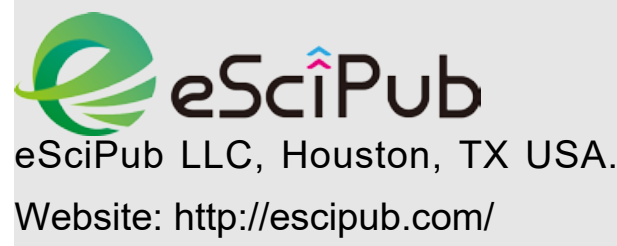




\section{INTRODUCTION}

In the West the arrival of old age is largely related to losses, whether physical and / or psychological deficits, social isolation, loss of work capacity, among others. It is a fact that a considerable portion of the elderly population has some potentially limiting disease, but also the stereotyping of the elderly, who generalizes it as a fragile and isolated socially, with a high propensity to diseases and without great expectations taking away important human aspects, such as the possibility of learning, of entering new social groups and even having a satisfactory sexual life. (PAPALIA; OLDS, 2000).

The cultural reinforcement of characteristics such as physical and mental fragility, creates an environment conducive to the installation of depression in the elderly population. Depression may be associated with some type of loss in physical ability, appearance, social role, death of others, financial security. Depressed adults feel as if their world has narrowed, their choices got smaller, their interests less and their preferences less available. They feel an unbearable sadness. Suicidal ideation is associated with the need for the elderly to resolve or, finally, an intolerable situation, feelings of hopelessness, and the inability to do things better. Depression is often accompanied by somatizations and physical complaints. The symptoms of depression are: exaggerated anxiety; dependency accompanied by guilt; rigidity alternated by impulsivity (MITTY et al., 2008).

The diagnosis is made late in the majority of elderly individuals, because they present a less characteristic clinical picture, with more organic symptoms (fatigue, insomnia, pain, weight loss, dizziness, forgetfulness) and, in general, less frank sadness than the young adult. Depression is often not identified as a disease by the erroneous belief that the elderly individual is more apathetic or more "grouchy"; aging only exacerbates preexisting personality traits, and does not modify behavior. Over time, families are finding it difficult and also physical and emotional to care for their elderly. As this is an increasingly present reality, it is necessary to have a long-term institution for the elderly, formerly known as asylum or known as shelter, nursing home, nursing home, and nursing home (TIER et al., 2008).

The elderly living in a long-term institution live apart from the family environment, in the presence of strangers and often isolated, feeling abandoned, dependent and useless, presenting a picture of insecurity, discontent and a lack of intimacy. This whole process can be a factor predisposing to depression even if the patient has no history of the disease or the family history of the disease (MIGUEL JUNIOR, 2007).

According to the above, it is necessary to diagnose depression and depression with suicidal ideation in the elderly, so that it is possible to follow up and treat it. This study aims to analyze the depression disorder and suicidal ideation in a population of institutionalized elderly people in the city of Recife Pernambuco, to determine the frequencies of depression and suicidal ideation in the studied group, to identify the degree of depression most found in this population, as well as to verify if, for the group studied, the relationship between depression and suicidal ideation is confirmed.

\section{METHODOLOGY}

\section{TYPOLOGY AND STUDY LOCATION}

Descriptive and cross-sectional research with primary data collection conducted from August to October 2014, in long-term institutions in the city of Recife.

\section{POPULATION}

Elderly people with 60 years of age or older residing in long-term institutions in the city of Recife and who met the following inclusion criteria: they did not present any systemic or neurological condition that made participation in the study unfeasible; and accepted to participate in the research translating such acceptance with the signature of the TCLE.

\section{DATA COLLECT}

To measure the phenomena under study two standardized scales were adopted. For suicidal ideation BECK SCALE FOR SUICIDE IDEATION (BSI) was adopted and for depression the GERIATRIC DEPRESSION SCALE (EDG / GDS).

Beck's suicidal ideation scale (BSI; BECK; KOVACS; WEISSMAN, 1979), in turn, is a measure composed of 21 items to evaluate 
predictors of suicide in adults. The first 19 items, with a response format with three multiple choice options for each of them, which reflect degrees of severity of desires, attitudes, and suicidal plans. The last 2 items, of an informative nature, are not included in the final result. The measure allows to obtain a total result, that varies between 0 and 38, in the sense of greater seriousness of the suicidal ideation.

The scale to verify the level of geriatric depression was the reduced scale of ALMEIDA (1999), developed from the scale of YESAVAGE (1983), to measure the depression in the elderly consists of 15 items, with a format of dichotomous response, yes or not, and can be read to the elderly in an interview or can be completed independently. Items 1, 5, 7, 11, 13 should be reversed. The quotation of the Geriatric Depression Scale is made from the attribution of 1 point for each depressive item and 0 points for each non-depressive item, allowing values between 0 to 15 , in the sense that higher values correspond to more depression. The authors of the scale presented as cutoff points: between 0 to 5 - normal mood state; between 6 to 10 - elderly with depression of increasing severity; between 11 to 15 severely depressed elderly.

The data of the scales were transferred to the worksheet in MS EXCEL OFFICE XP program and the statistical analyzes were obtained through the program of the statistical package EPI-INFO.
The data of the scales were transferred to the worksheet in MS EXCEL OFFICE XP program and the statistical analyzes were obtained through the program of the statistical package EPI-INFO.

\section{PROCEDURE}

Initially, six persons aged 65 and over, three women and three men were requested to complete the protocol in order to know the average duration of completion and if there were any doubts about the issues raised. After the experiment, the protocol was applied to 50 elderly people.

All participants were questioned individually and under conditions that allowed them to maintain confidentiality. The questions were asked orally and the questionnaires were read and completed by the investigator.

\section{DATA ANALYSIS}

The data collected were entered into a database, and statistical procedures were performed by the Statistical Package for Social Sciences (SPSS) version 13.0 for Windows.

\section{RESULTS AND DISCUSSION}

Of the total of 96 elderly people living in the three long-term institutions that accepted to participate in the study, 50 elderly people met the inclusion criteria. From table 1 it is possible to show that the majority of the surveyed elderly were female, in the age range of 70 to 89 years, with the mean age of the sample being 82.5 years. The predominance of women in the present study may be due, according to Chaimowics and Greco (1999), to the fact that they live longer than men and become widows earlier.

Table 1 - Characterization of the sample according to sex, and the score reached in the Beck Suicidal Ideation Scale. Recife - PE, 2015

\begin{tabular}{l|r|r}
\multicolumn{1}{c|}{ SEX } & N $(=50)$ & $\%$ \\
\hline Male & 5 & 10,0 \\
Female & 45 & 90,0 \\
\hline \multicolumn{1}{c|}{ FAIXA ETARIA } & & \\
\hline 60 a 69 years & 3 & 6,0 \\
70 a 79 years & 18 & 36,0
\end{tabular}




\begin{tabular}{l|r|r}
80 a 89 years & 17 & 34,0 \\
90 anos ou + & 6 & 12,0 \\
Not Informed & 6 & 12,0 \\
\hline BSI SCORE (Suicidal Ideation Scale) & & \\
\hline 0 & 29 & 58,0 \\
1 & 3 & 6,0 \\
2 & 7 & 14,0 \\
3 & 2 & 4,0 \\
4 & 1 & 2,0 \\
5 & 2 & 4,0 \\
6 & 2 & 4,0 \\
8 & 1 & 2,0 \\
10 & 1 & 2,0 \\
17 & 1 & 2,0 \\
25 & 1 & 2,0 \\
\hline
\end{tabular}

Source: Direct Search

According to data from BSI (still in Table 1), it was possible to verify that $58 \%$ of the elderly scored zero (fashion), with the average score being 2.18. This is an important fact considering that the vast majority of the elderly do not think about suicide. During the interview, they demonstrated a certain repudiation when talking about the subject, but, in contrast, the small number of people reported having tried to commit suicide (8\%), $50 \%$ are in treatment for depression and another $50 \%$ say still think of suicide. These participants corresponded to $4 \%$ $(\mathrm{N}=2)$ of the total population studied, which presented a score equivalent to $45 \%$ and $65 \%$ of suicidal thoughts. Presenting fixed idea of suicide and claim to have already chosen the way, but that does not attempt for lack of access to the selected method.

According to Beeston (2006) the prevalence of suicide attempt is $61 / 100,000$, being between attempts and suicide of the elderly of $4 / 1$, considering these data the frequency of ideation with suicide attempt in the present study is quite relevant considered the small sample number $4 / 50$. Life expectancy is described by specialized literature as one of the most common feelings of the individual at risk of suicide (CORREA; BARRERO, 2006; BOTEGA et al., 2006; BAPTISTA, 2004) and is related to defeatist thoughts and a negative outlook for the future (BECK et al., 1997).

According to the Manual of Suicide Prevention, prepared by the Ministry of Health, despair is pointed out as one of the risk factors for the consummation, or at least attempt, of the suicide act. This feeling is part of the so-called "4D rule", which highlights as risk indicators for suicidal behavior, as well as hopelessness, depression, helplessness and despair (Brazil, 2006).

According to the data obtained through the Geriatric Depression Scale (EDG / GDS) (Table 2 ), we can verify that $48 \%$ of the elderly population interviewed are with some degree of depression, with $4 \%$ classified as severely depressed elderly (11 to 15 points) and 44\% with increasing severity depression (6 to 10 points), $52 \%$ of the interviewees were classified as normal for depression ( 0 to 5 points). The mean EDG responses were 5.18 and the fashion was 9 points, since this was the score obtained by $18 \%$ of the participants. According to Brazil (2007) and Mclntyre (2007) the picture of mild depression is characterized by several 
symptoms of lower intensity that can be found in severe depression. However, in severe depression, the individual may experience a greater exacerbation of paranoia of disappointment and lack of purpose. According to MOREIRA (2005), the occurrence of depression is associated with factors such as age, marital status, social class and social status. It is a condition that affects all individuals at some stage in their lives, either as a transient mood when feeling depressed or melancholic, or as a more serious form, which can impair physical and psychological performance. Ferrari and Dalacorte (2007) in a study carried out with 50 elderly hospitalized patients, found a $46 \%$ depression rate through the use of EGD. These data corroborate with the present study since the same instrument and number of participants were used, and the indices of depression were quite similar.

Table 2 - Characterization of the sample according to the score reached in the Geriatric Depression Scale and the diagnosis related to the depressive picture. Recife - PE, 2015

\begin{tabular}{l|r|r}
\hline EGD SCORE (Geriatric Depression Scale) & $\mathrm{N}(=50)$ & $\%(100,0)$ \\
\hline 0 & 4 & 2,0 \\
1 & 8 & 8,0 \\
2 & 5 & 16,0 \\
3 & 5 & 10,0 \\
4 & 3 & 10,0 \\
5 & 5 & 6,0 \\
6 & 3 & 10,0 \\
7 & 4 & 6,0 \\
8 & 9 & 8,0 \\
9 & 1 & 18,0 \\
10 & 1 & 2,0 \\
11 & 1 & 2,0 \\
13 & & 2,0 \\
\hline & 26 \\
\hline Normal & 2 & \\
Of increasing severity & 2 & 52,0 \\
Serious & 2,0 \\
\hline
\end{tabular}

Source: Direct Search

According to the data presented in table 3, 80\% of the males are depressed, while in the female, the index was 44\%. In Research involving 9,294 elderly Ryan et al. (2008) showed a distribution of the depressive picture regarding sex, evidencing that the manifestation is higher in women, this refutes the data obtained in our studies, but can be explained by the small number of male participants $\mathrm{N}=5$.
Table 4 highlights the fact that approximately 39 $\%$ of elderly people in the 70-79 age group suffer from depression, which is even higher in the 80 89 age group with approximately $53 \%$. The finding that advancing age leads to an increase in the number of depressed elderly people is corroborated by the studies by Rothermund and Brandtstadter (2003) and Nguyen and Zonderman (2006), when they affirm that the 
depressive symptomatology in adults less than 70 years old tends to be stable the same not happening at subsequent ages when they tend to increase.

The elderly in the age groups of 60 to 69 years and of 90 or more, presented 66 and $50 \%$ of depression, this can be considered an important finding, even though the number of participants in each group is small, according to Siqueira (2007) the process of the population aging in progress in the country has increased the frequency of psychiatric diseases, among them, depression, which is the most common disorder in this age group. According to the author, prevalence rates vary between $5 \%$ and $35 \%$ when we consider the different forms and severity of depression. In our study, depression rates are higher than those found by Siqueira (2007). being found, in its moderate state, varying from 33.3 to 66.7 along the age ranges and in its severe state in $16.7 \%$ of the individuals of 90 or more.

Table 3 - Distribution of cases according to diagnosis for depression and sex. Recife - PE, 2015

\begin{tabular}{|c|c|c|c|c|c|}
\hline & \multirow{2}{*}{ SEX } & \multicolumn{3}{|c|}{ DIAGNÓSTICO PARA A DEPRESSÃO } & \multirow{2}{*}{ TOTAL } \\
\hline & & Normal & De severidade crescente & Grave & \\
\hline \multirow{3}{*}{ Male } & Count & 1 & 4 & 0 & 5 \\
\hline & $\% \operatorname{sex}$ & 20,0 & 80,0 & , 0 & 100,0 \\
\hline & $\%$ ResultEGD & 3,8 & 18,2 & ,0 & 10,0 \\
\hline \multirow{3}{*}{ Female } & Count & 25 & 18 & 2 & 45 \\
\hline & $\% \operatorname{sex}$ & 55,6 & 40,0 & 4,4 & 100,0 \\
\hline & \%ResultEGD & 96,2 & 81,8 & 100,0 & 90,0 \\
\hline \multirow{3}{*}{ Total } & Count & 26 & 22 & 2 & 50 \\
\hline & $\% \operatorname{sex}$ & 52,0 & 44,0 & 4,0 & 100,0 \\
\hline & $\%$ ResultEGD & 100,0 & 100,0 & 100,0 & 100,0 \\
\hline
\end{tabular}

Source: Direct Search

Table 4 - Distribution of cases according to diagnosis for depression and age group. Recife - PE, 2015.

\begin{tabular}{|c|c|c|c|c|c|}
\hline & & \multicolumn{3}{|c|}{ DIAGNÓSTICO PARA A DEPRESSÃO } & \multirow[b]{2}{*}{ Base } \\
\hline \multicolumn{2}{|c|}{ FAIXA ETARIA } & Normol & De severidade & Grave & \\
\hline \multirow{3}{*}{60 a 69 anos } & Count & 1 & 2 & 0 & 3 \\
\hline & \%faixa & 33,3 & 66,7 & 0 & 100,0 \\
\hline & $\%$ ResultEGD & 4,3 & 10,5 & 0 & 6,8 \\
\hline \multirow{3}{*}{70 a 79 anos } & Count & 11 & 6 & 1 & 18 \\
\hline & \%faixa & 61,1 & 33,3 & 5,6 & 100,0 \\
\hline & $\%$ ResultEGD & 47,8 & 31,6 & 50,0 & 40,9 \\
\hline \multirow{3}{*}{80 a 89 anos } & Count & 8 & 9 & 0 & 17 \\
\hline & $\%$ faixa & 47,1 & 52,9 & 0 & 100,0 \\
\hline & \%ResultEGD & 34,8 & 47,4 & ,0 & 38,6 \\
\hline \multirow{3}{*}{90 ou +} & Count & 3 & 2 & 1 & 6 \\
\hline & $\%$ faixa & 50,0 & 33,3 & 16,7 & 100,0 \\
\hline & \%ResulTEGD & 13,0 & 10,5 & 50,0 & 13,6 \\
\hline \multirow{3}{*}{ Base } & Count & 23 & 19,0 & 2 & 44 \\
\hline & $\%$ faixa & 52,3 & 43,2 & 4,5 & 100,0 \\
\hline & \%ResultEGD & 100,0 & 100,0 & 100,0 & 100,0 \\
\hline
\end{tabular}


According to degree of severity, depression can be classified as mild, moderate and severe. However, for the diagnosis of the depressive episode, two of the three main symptoms (depressed mood, reduced energy or loss of interest and pleasure) and two of the other symptoms (decreased self-esteem, suicidal ideation) must be present accompanied by functional or social interference (CORDIOLI et al., 2008). Some individuals face aging as a negative life process, associating it with dependency, or the need for a better income for survival (Mclntyre et al., 2007).

From the data expressed in table 5 , it is possible to observe that suicidal ideation is more pronounced in women, since these presented higher scores. The male score was between 0 and 6 points, while in the women, for some participants, scores between 8 and 25 were observed. Being characterized as high risk patients for suicidal ideation. This represents 21 $66 \%$ of suicidal thoughts. The mean value of suicidal ideation in the sample is $6 \%$. Of the elderly women with a risk factor for ideation, the following reasons were verified: loss of vision; loss of lower limb; death of son by suicide and solitude. According to Minayo and Cavalcante (2010), the presence of some serious diseases is considered a risk factor for the suicide of elderly people. This is corroborated by Beeston (2006) when he says that the experience of a serious physical illness can provoke depression in the elderly (considered a triggering factor), but there is no direct relation between the state of physical health and ideation or suicide attempt. Regarding social isolation and solitude De Leo et al. (2001) affirm that these conditions are the main reasons for suicidal ideation.

In Table 6, it is possible to observe the distribution of the cases according to the score obtained in the EGD scale and the sex, evidencing that although $80 \%$ of the men are depressed, this depression is characterized as of increasing severity. On the other hand, depression in women was manifested in the following way: in $40 \%$ of them, as severity increased and $4.4 \%$ presented severe depression. This is corroborated by Olson and Von Knorring (1997) who state that the symptoms in women are more severe and more frequent due to the rumination condition, that is, women tend to reflect more depressive ideas than men.

As shown in table 7 , suicidal ideation is more present in individuals aged 70-79 years. This data corroborates with Stek et al. (2006), when he reports that older people are at greater risk of developing more persistent depression. Forsell (2000) found a correlation between depression or anxiety and suicidal ideation and said that having physical and incapacitating problems for day-to-day tasks are also predisposing factors. For Takeda, (2010) agitated depression is frequent in the elderly, who do not present an obvious depressive mood in the foreground, showing only agitation and irritation, which are more prone to suicide and self-injury. Life expectancy is described by specialized literature as one of the most common feelings of the individual at risk of suicide (CORREA; BARRERO, 2006; BOTEGA et al., 2006; BAPTISTA, 2004).

Table 5 - Distribution of cases according to the score obtained on the BSI scale and sex. Recife - PE, 2015

\begin{tabular}{c|l|r|r|r}
\hline \multirow{2}{*}{\multicolumn{2}{c|}{ BSI SCALE SCORE }} & \multicolumn{2}{c}{ SEXO } & \multicolumn{2}{c}{ TOTAL } \\
\cline { 3 - 4 } \multicolumn{2}{c|}{} & \multicolumn{2}{|c|}{ MALE } & \multicolumn{2}{c}{ FEMALE } & \\
\hline \multirow{3}{*}{0} & Count & 2 & 27 & 29 \\
& \% within ResultBSI & $6,9 \%$ & $93,1 \%$ & $100,0 \%$ \\
& \% within sexo & $40,0 \%$ & $60,0 \%$ & $58,0 \%$ \\
\hline \multirow{2}{*}{1} & Count & 0 & 3 & 3 \\
\hline
\end{tabular}


Evandro Valentim da Silva et al., IJOAR, 2019 2:36

\begin{tabular}{|c|c|c|c|c|}
\hline & $\begin{array}{l}\text { \% within ResultBSI } \\
\% \text { within sexo }\end{array}$ & $\begin{array}{l}, 0 \% \\
, 0 \%\end{array}$ & $\begin{array}{r}100,0 \% \\
6,7 \%\end{array}$ & $\begin{array}{r}100,0 \% \\
6,0 \%\end{array}$ \\
\hline 2 & $\begin{array}{l}\text { Count } \\
\% \text { within ResultBSI } \\
\% \text { within sexo }\end{array}$ & $\begin{array}{r}0 \\
, 0 \% \\
, 0 \%\end{array}$ & $\begin{array}{r}7 \\
100,0 \% \\
15,6 \%\end{array}$ & $\begin{array}{r}7 \\
100,0 \% \\
14,0 \%\end{array}$ \\
\hline 3 & $\begin{array}{l}\text { Count } \\
\% \text { within ResultBSI } \\
\% \text { within sexo }\end{array}$ & $\begin{array}{r}1 \\
50,0 \% \\
20,0 \%\end{array}$ & $\begin{array}{r}1 \\
50,0 \% \\
2,2 \%\end{array}$ & $\begin{array}{r}2 \\
100,0 \% \\
4,0 \%\end{array}$ \\
\hline 4 & $\begin{array}{l}\text { Count } \\
\% \text { within ResultBSI } \\
\% \text { within sexo }\end{array}$ & $\begin{array}{r}0 \\
, 0 \% \\
, 0 \%\end{array}$ & $\begin{array}{r}1 \\
100,0 \% \\
2,2 \%\end{array}$ & $\begin{array}{r}1 \\
100,0 \% \\
2,0 \%\end{array}$ \\
\hline 5 & $\begin{array}{l}\text { Count } \\
\% \text { within ResultBSI } \\
\% \text { within sexo }\end{array}$ & $\begin{array}{r}1 \\
50,0 \% \\
20,0 \%\end{array}$ & $\begin{array}{r}1 \\
50,0 \% \\
2,2 \%\end{array}$ & $\begin{array}{r}2 \\
100,0 \% \\
4,0 \%\end{array}$ \\
\hline 6 & $\begin{array}{l}\text { Count } \\
\% \text { within ResultBSI } \\
\% \text { within sexo }\end{array}$ & $\begin{array}{r}1 \\
50,0 \% \\
20,0 \%\end{array}$ & $\begin{array}{r}1 \\
50,0 \% \\
2,2 \%\end{array}$ & $\begin{array}{r}2 \\
100,0 \% \\
4,0 \%\end{array}$ \\
\hline 8 & $\begin{array}{l}\text { Count } \\
\% \text { within ResultBSI } \\
\% \text { within sexo }\end{array}$ & $\begin{array}{r}0 \\
, 0 \% \\
, 0 \%\end{array}$ & $\begin{array}{r}1 \\
100,0 \% \\
2,2 \%\end{array}$ & $\begin{array}{r}1 \\
100,0 \% \\
2,0 \%\end{array}$ \\
\hline 10 & $\begin{array}{l}\text { Count } \\
\% \text { within ResultBSI } \\
\% \text { within sexo }\end{array}$ & $\begin{array}{r}0 \\
, 0 \% \\
, 0 \%\end{array}$ & $\begin{array}{r}1 \\
100,0 \% \\
2,2 \%\end{array}$ & $\begin{array}{r}1 \\
100,0 \% \\
2,0 \%\end{array}$ \\
\hline 17 & $\begin{array}{l}\text { Count } \\
\% \text { within ResultBSI } \\
\% \text { within sexo }\end{array}$ & $\begin{array}{r}0 \\
, 0 \% \\
, 0 \%\end{array}$ & $\begin{array}{r}1 \\
100,0 \% \\
2,2 \%\end{array}$ & $\begin{array}{r}1 \\
100,0 \% \\
2,0 \%\end{array}$ \\
\hline 25 & $\begin{array}{l}\text { Count } \\
\% \text { within ResultBSI } \\
\% \text { within sexo }\end{array}$ & $\begin{array}{r}0 \\
, 0 \% \\
, 0 \% \\
\end{array}$ & $\begin{array}{r}1 \\
100,0 \% \\
2,2 \%\end{array}$ & $\begin{array}{r}1 \\
100,0 \% \\
2,0 \%\end{array}$ \\
\hline TOTAL & $\begin{array}{l}\text { Count } \\
\% \text { within ResultBSI } \\
\% \text { within sexo }\end{array}$ & $\begin{array}{r}5 \\
10,0 \% \\
100,0 \%\end{array}$ & $\begin{array}{r}45 \\
90,0 \% \\
100,0 \%\end{array}$ & $\begin{array}{r}50 \\
100,0 \% \\
100,0 \%\end{array}$ \\
\hline
\end{tabular}

Table 6 - Distribution of the cases according to the score obtained in the EGD scale and the sex. Recife - PE, 2015.

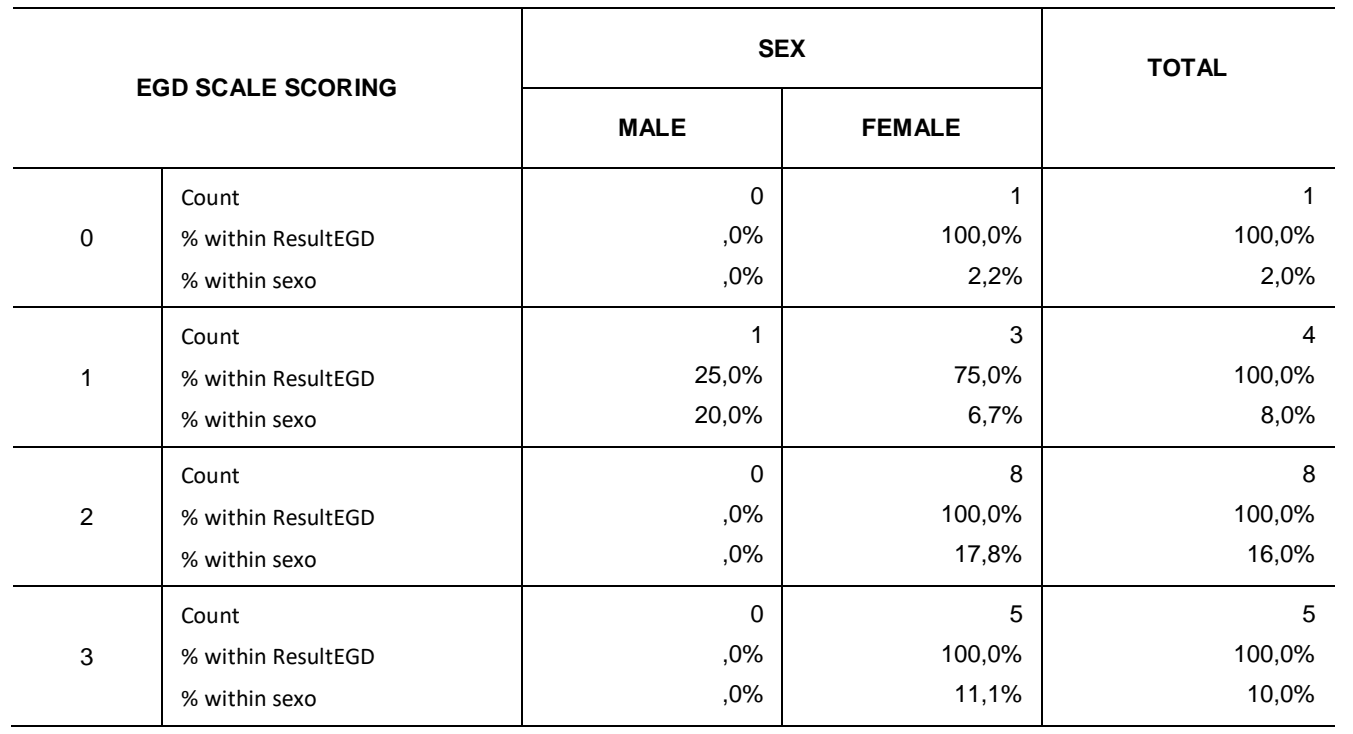




\begin{tabular}{|c|c|c|c|c|}
\hline 4 & $\begin{array}{l}\text { Count } \\
\% \text { within ResultEGD } \\
\% \text { within sexo }\end{array}$ & $\begin{array}{r}0 \\
0 \\
, 0 \%\end{array}$ & $\begin{array}{r}5 \\
100,0 \% \\
11,1 \%\end{array}$ & $\begin{array}{r}5 \\
100,0 \% \\
10,0 \%\end{array}$ \\
\hline 5 & $\begin{array}{l}\text { Count } \\
\% \text { within ResultEGD } \\
\% \text { within sexo }\end{array}$ & $\begin{array}{r}0 \\
, 0 \% \\
, 0 \%\end{array}$ & $\begin{array}{r}3 \\
100,0 \% \\
6,7 \%\end{array}$ & $\begin{array}{r}3 \\
100,0 \% \\
6,0 \%\end{array}$ \\
\hline 6 & $\begin{array}{l}\text { Count } \\
\% \text { within ResultEGD } \\
\% \text { within sexo }\end{array}$ & $\begin{array}{r}1 \\
20,0 \% \\
20,0 \%\end{array}$ & $\begin{array}{r}4 \\
80,0 \% \\
8,9 \%\end{array}$ & $\begin{array}{r}5 \\
100,0 \% \\
10,0 \%\end{array}$ \\
\hline 7 & $\begin{array}{l}\text { Count } \\
\% \text { within ResultEGD } \\
\% \text { within sexo }\end{array}$ & $\begin{array}{r}0 \\
, 0 \% \\
, 0 \%\end{array}$ & $\begin{array}{r}3 \\
100,0 \% \\
6,7 \%\end{array}$ & $\begin{array}{r}3 \\
100,0 \% \\
6,0 \%\end{array}$ \\
\hline 8 & $\begin{array}{l}\text { Count } \\
\% \text { within ResultEGD } \\
\% \text { within sexo }\end{array}$ & $\begin{array}{r}1 \\
25,0 \% \\
20,0 \%\end{array}$ & $\begin{array}{r}3 \\
75,0 \% \\
6,7 \%\end{array}$ & $\begin{array}{r}4 \\
100,0 \% \\
8,0 \%\end{array}$ \\
\hline 9 & $\begin{array}{l}\text { Count } \\
\% \text { within ResultEGD } \\
\% \text { within sexo }\end{array}$ & $\begin{array}{r}2 \\
22,2 \% \\
40,0 \%\end{array}$ & $\begin{array}{r}7 \\
77,8 \% \\
15,6 \%\end{array}$ & $\begin{array}{r}9 \\
100,0 \% \\
18,0 \%\end{array}$ \\
\hline 10 & $\begin{array}{l}\text { Count } \\
\% \text { within ResultEGD } \\
\% \text { within sexo }\end{array}$ & $\begin{array}{r}0 \\
, 0 \% \\
, 0 \%\end{array}$ & $\begin{array}{r}1 \\
100,0 \% \\
2,2 \%\end{array}$ & $\begin{array}{r}1 \\
100,0 \% \\
2,0 \%\end{array}$ \\
\hline 11 & $\begin{array}{l}\text { Count } \\
\% \text { within ResultEGD } \\
\% \text { within sexo }\end{array}$ & $\begin{array}{r}0 \\
, 0 \% \\
, 0 \%\end{array}$ & $\begin{array}{r}1 \\
100,0 \% \\
2,2 \%\end{array}$ & $\begin{array}{r}1 \\
100,0 \% \\
2,0 \%\end{array}$ \\
\hline 13 & $\begin{array}{l}\text { Count } \\
\% \text { within ResultEGD } \\
\% \text { within sexo }\end{array}$ & $\begin{array}{r}0 \\
, 0 \% \\
, 0 \%\end{array}$ & $\begin{array}{r}1 \\
100,0 \% \\
2,2 \%\end{array}$ & $\begin{array}{r}1 \\
100,0 \% \\
2,0 \%\end{array}$ \\
\hline TOTAL & $\begin{array}{l}\text { Count } \\
\% \text { within ResultEGD } \\
\% \text { within sexo }\end{array}$ & $\begin{array}{r}5 \\
10,0 \% \\
100,0 \%\end{array}$ & $\begin{array}{r}45 \\
90,0 \% \\
100,0 \%\end{array}$ & $\begin{array}{r}50 \\
100,0 \% \\
100,0 \%\end{array}$ \\
\hline
\end{tabular}

Table 7 - Distribution of the cases according to the score obtained in the BSI scale and the age group. Recife - PE, 2015.

\begin{tabular}{|c|c|c|c|c|c|c|}
\hline & & \multicolumn{4}{|c|}{$\mathrm{AGE}$} & \multirow{2}{*}{ TOTAL } \\
\hline \multicolumn{2}{|c|}{ BSI SCALE SCORE } & $60-69$ & $70-79$ & $80-89$ & 90 ou + & \\
\hline \multirow{3}{*}{0} & Count & 1 & 12 & 11 & 3 & 27 \\
\hline & $\%$ within ResultBSI & $3,7 \%$ & $44,4 \%$ & $40,7 \%$ & $11,1 \%$ & $100,0 \%$ \\
\hline & $\%$ within sexo & $33,3 \%$ & $66,7 \%$ & $64,7 \%$ & $50,0 \%$ & $61,4 \%$ \\
\hline \multirow{3}{*}{1} & Count & 0 & 0 & 1 & 0 & 1 \\
\hline & $\%$ within ResultBSI & ,0\% &, $0 \%$ & $100,0 \%$ &, $0 \%$ & $100,0 \%$ \\
\hline & $\%$ within sexo &, $0 \%$ &, $0 \%$ & $5,9 \%$ & ,0\% & $2,3 \%$ \\
\hline \multirow{3}{*}{2} & Count & 1 & 0 & 3 & 2 & 6 \\
\hline & $\%$ within ResultBSI & $16,7 \%$ &, $0 \%$ & $50,0 \%$ & $33,3 \%$ & $100,0 \%$ \\
\hline & $\%$ within sexo & $33,3 \%$ &, $0 \%$ & $17,6 \%$ & $33,3 \%$ & $13,6 \%$ \\
\hline \multirow{3}{*}{3} & Count & 0 & 2 & 0 & 0 & 2 \\
\hline & $\%$ within ResultBSI & ,0\% & $100,0 \%$ & ,0\% &, $0 \%$ & $100,0 \%$ \\
\hline & $\%$ within sexo &, $0 \%$ & $11,1 \%$ &, $0 \%$ &, $0 \%$ & $4,5 \%$ \\
\hline \multirow{3}{*}{4} & Count & 0 & 0 & 1 & 0 & 1 \\
\hline & $\%$ within ResultBSI &, $0 \%$ &, $0 \%$ & $100,0 \%$ &, $0 \%$ & $100,0 \%$ \\
\hline & $\%$ within sexo &, $0 \%$ &, $0 \%$ & $5,9 \%$ &, $0 \%$ & $2,3 \%$ \\
\hline 5 & Count & 0 & 1 & 1 & 0 & 2 \\
\hline
\end{tabular}




\begin{tabular}{c|l|r|r|r|r|r}
\hline & \% within ResultBSI &, $0 \%$ & $50,0 \%$ & $50,0 \%$ &, $0 \%$ & $100,0 \%$ \\
& \% within sexo &, $0 \%$ & $5,6 \%$ & $5,9 \%$ &, $0 \%$ & $4,5 \%$ \\
\hline \multirow{3}{*}{6} & Count & 0 & 1 & 0 & 1 & 2 \\
& \% within ResultBSI &, $0 \%$ & $50,0 \%$ &, $0 \%$ & $50,0 \%$ & $100,0 \%$ \\
& \% within sexo &, $0 \%$ & $5,6 \%$ &, $0 \%$ & $16,7 \%$ & $4,5 \%$ \\
\hline \multirow{3}{*}{8} & Count & 0 & 1 & 0 & 0 & 1 \\
& \% within ResultBSI &, $0 \%$ & $100,0 \%$ &, $0 \%$ &, $0 \%$ & $100,0 \%$ \\
& \% within sexo &, $0 \%$ & $5,6 \%$ &, $0 \%$ &, $0 \%$ & $2,3 \%$ \\
\hline \multirow{3}{*}{17} & Count & 1 & 0 & 0 & 0 & 1 \\
& \% within ResultBSI & $100,0 \%$ &, $0 \%$ &, $0 \%$ &, $0 \%$ & $100,0 \%$ \\
& \% within sexo & $33,3 \%$ &, $0 \%$ &, $0 \%$ &, $0 \%$ & $2,3 \%$ \\
\hline \multirow{3}{*}{25} & Count & 0 & 1 & 0 & 0 & 1 \\
& \% within ResultBSI &, $0 \%$ & $100,0 \%$ &, $0 \%$ &, $0 \%$ & $100,0 \%$ \\
& \% within sexo &, $0 \%$ & $5,6 \%$ &, $0 \%$ &, $0 \%$ & $2,3 \%$ \\
\hline \multirow{3}{*}{ TOTAL } & Count & 3 & 18 & 17 & 6 & 44 \\
& \% within ResultBSI & $6,8 \%$ & $40,9 \%$ & $38,6 \%$ & $13,6 \%$ & $100,0 \%$ \\
& \%ithin sexo & $100,0 \%$ & $100,0 \%$ & $100,0 \%$ & $100,0 \%$ & $100,0 \%$ \\
\hline
\end{tabular}

Source: Direct Search

According to data shown in table 8 , it is possible to observe that the depressive pictures are more frequent in the elderly in the range of $70-89$ being slightly higher in the 80-89 years. This corroborates with Ferrari and Dalacorte (2007) when he states that the increase in the number of individuals over $80 / 90$ years contributes to the increase in the prevalence of depression in the third age. The high rates of depression found in the present study may be due to the large number of elderly people in the study (52 $\%)$. According to Stek et al. (2006), it is the older people who are at greater risk of developing depression of the more persistent type. Depression in the elderly is often not identified in the primary health sector and the prognosis of these cases is worse (LICHT-STRUNK et al., 2010).

Table 8 - Distribution of the cases according to the score obtained in the EGD scale and the age group. Recife - PE, 2015

\begin{tabular}{|c|c|c|c|c|c|c|}
\hline \multicolumn{2}{|c|}{ EGD SCALE SCORING } & \multicolumn{4}{|c|}{ ETERNAL TRACK } & \multirow{2}{*}{$\begin{array}{r}\text { TOTAL } \\
1\end{array}$} \\
\hline & & $60-69$ & $70-79$ & $80-89$ & $900 u_{+}$ & \\
\hline 0 & $\begin{array}{l}\text { Count } \\
\% \text { within ResultEGD } \\
\% \text { within sexo }\end{array}$ & $\begin{array}{r}0 \\
, 0 \% \\
, 0 \%\end{array}$ & $\begin{array}{r}1 \\
100,0 \% \\
5,6 \%\end{array}$ & $\begin{array}{r}0 \\
, 0 \% \\
, 0 \%\end{array}$ & $\begin{array}{r}0 \\
, 0 \% \\
, 0 \%\end{array}$ & $\begin{array}{r}1 \\
100,0 \% \\
2,3 \%\end{array}$ \\
\hline 1 & $\begin{array}{l}\text { Count } \\
\% \text { within ResultEGD } \\
\% \text { within sexo }\end{array}$ & $\begin{array}{r}0 \\
, 0 \% \\
, 0 \%\end{array}$ & $\begin{array}{r}3 \\
75,0 \% \\
16,7 \%\end{array}$ & $\begin{array}{r}1 \\
25,0 \% \\
5,9 \%\end{array}$ & $\begin{array}{r}0 \\
, 0 \% \\
, 0 \%\end{array}$ & $\begin{array}{r}4 \\
100,0 \% \\
9,1 \%\end{array}$ \\
\hline 2 & $\begin{array}{l}\text { Count } \\
\% \text { within ResultEGD } \\
\% \text { within sexo }\end{array}$ & $\begin{array}{r}0 \\
, 0 \% \\
, 0 \%\end{array}$ & $\begin{array}{r}3 \\
42,9 \% \\
16,7 \%\end{array}$ & $\begin{array}{r}3 \\
42,9 \% \\
17,6 \%\end{array}$ & $\begin{array}{r}1 \\
14,3 \% \\
16,7 \%\end{array}$ & $\begin{array}{r}7 \\
100,0 \% \\
15,9 \%\end{array}$ \\
\hline 3 & $\begin{array}{l}\text { Count } \\
\% \text { within ResultEGD } \\
\% \text { within sexo }\end{array}$ & $\begin{array}{l}0 \\
, 0 \% \\
, 0 \%\end{array}$ & $\begin{array}{l}2 \\
50,0 \% \\
11,1 \%\end{array}$ & $\begin{array}{l}2 \\
50,0 \% \\
11,8 \%\end{array}$ & $\begin{array}{l}0 \\
, 0 \% \\
, 0 \%\end{array}$ & $\begin{array}{l}4 \\
100,0 \% \\
9,1 \%\end{array}$ \\
\hline 4 & $\begin{array}{l}\text { Count } \\
\% \text { within ResultEGD } \\
\% \text { within sexo }\end{array}$ & $\begin{array}{l}1 \\
25,0 \% \\
33,3 \%\end{array}$ & $\begin{array}{l}2 \\
50,0 \% \\
11,1 \%\end{array}$ & $\begin{array}{l}1 \\
25,0 \% \\
5,9 \%\end{array}$ & $\begin{array}{l}0 \\
, 0 \% \\
, 0 \%\end{array}$ & $\begin{array}{l}4 \\
100,0 \% \\
9,1 \%\end{array}$ \\
\hline 5 & $\begin{array}{l}\text { Count } \\
\% \text { within ResultEGD }\end{array}$ & $\begin{array}{l}0 \\
, 0 \%\end{array}$ & $\begin{array}{l}0 \\
, 0 \%\end{array}$ & $\begin{array}{l}1 \\
33,3 \%\end{array}$ & $\begin{array}{l}2 \\
66,7 \%\end{array}$ & $\begin{array}{l}3 \\
100,0 \%\end{array}$ \\
\hline
\end{tabular}




\begin{tabular}{|c|c|c|c|c|c|c|}
\hline & $\%$ within sexo &, $0 \%$ &, $0 \%$ & $5,9 \%$ & $33,3 \%$ & $6,8 \%$ \\
\hline 6 & $\begin{array}{l}\text { Count } \\
\% \text { within ResultEGD } \\
\% \text { within sexo }\end{array}$ & $\begin{array}{l}0 \\
, 0 \% \\
, 0 \%\end{array}$ & $\begin{array}{l}2 \\
40,0 \% \\
11,1 \%\end{array}$ & $\begin{array}{l}3 \\
60,0 \% \\
17,6 \%\end{array}$ & $\begin{array}{l}0 \\
, 0 \% \\
, 0 \%\end{array}$ & $\begin{array}{l}5 \\
100,0 \% \\
11,4 \%\end{array}$ \\
\hline 7 & $\begin{array}{l}\text { Count } \\
\% \text { within ResultEGD } \\
\% \text { within sexo }\end{array}$ & $\begin{array}{l}0 \\
, 0 \% \\
, 0 \%\end{array}$ & $\begin{array}{l}1 \\
50,0 \% \\
5,6 \%\end{array}$ & $\begin{array}{l}1 \\
50,0 \% \\
5,9 \%\end{array}$ & $\begin{array}{l}0 \\
, 0 \% \\
, 0 \%\end{array}$ & $\begin{array}{l}2 \\
100,0 \% \\
4,5 \%\end{array}$ \\
\hline 8 & $\begin{array}{l}\text { Count } \\
\% \text { within ResultEGD } \\
\% \text { within sexo }\end{array}$ & $\begin{array}{l}0 \\
, 0 \% \\
, 0 \%\end{array}$ & $\begin{array}{l}1 \\
33,3 \% \\
5,6 \%\end{array}$ & $\begin{array}{l}2 \\
66,7 \% \\
11,8 \%\end{array}$ & $\begin{array}{l}0 \\
, 0 \% \\
, 0 \%\end{array}$ & $\begin{array}{l}3 \\
100,0 \% \\
6,8 \%\end{array}$ \\
\hline 9 & $\begin{array}{l}\text { Count } \\
\% \text { within ResultEGD } \\
\% \text { within sexo }\end{array}$ & $\begin{array}{l}2 \\
22,2 \% \\
66,7 \%\end{array}$ & $\begin{array}{l}2 \\
22,2 \% \\
11,1 \%\end{array}$ & $\begin{array}{l}3 \\
33,3 \% \\
17,6 \%\end{array}$ & $\begin{array}{l}2 \\
22,2 \% \\
33,3 \%\end{array}$ & $\begin{array}{l}9 \\
100,0 \% \\
20,5 \%\end{array}$ \\
\hline 11 & $\begin{array}{l}\text { Count } \\
\% \text { within ResultEGD } \\
\% \text { within sexo }\end{array}$ & $\begin{array}{l}0 \\
, 0 \% \\
, 0 \%\end{array}$ & $\begin{array}{l}0 \\
, 0 \% \\
, 0 \%\end{array}$ & $\begin{array}{l}0 \\
, 0 \% \\
, 0 \%\end{array}$ & $\begin{array}{l}1 \\
100,0 \% \\
16,7 \%\end{array}$ & $\begin{array}{l}1 \\
100,0 \% \\
2,3 \%\end{array}$ \\
\hline 13 & $\begin{array}{l}\text { Count } \\
\% \text { within ResultEGD } \\
\% \text { within sexo }\end{array}$ & $\begin{array}{l}0 \\
, 0 \% \\
, 0 \%\end{array}$ & $\begin{array}{l}1 \\
100,0 \% \\
5,6 \%\end{array}$ & $\begin{array}{l}0 \\
, 0 \% \\
, 0 \%\end{array}$ & $\begin{array}{l}0 \\
, 0 \% \\
, 0 \%\end{array}$ & $\begin{array}{l}1 \\
100,0 \% \\
2,3 \%\end{array}$ \\
\hline TOTAL & $\begin{array}{l}\text { Count } \\
\% \text { within ResultEGD } \\
\% \text { within sexo }\end{array}$ & $\begin{array}{l}3 \\
6,8 \% \\
100,0 \%\end{array}$ & $\begin{array}{l}18 \\
40,9 \% \\
100,0 \%\end{array}$ & $\begin{array}{l}17 \\
38,6 \% \\
100,0 \%\end{array}$ & $\begin{array}{l}6 \\
13,6 \% \\
100,0 \%\end{array}$ & $\begin{array}{l}44 \\
100,0 \% \\
100,0 \%\end{array}$ \\
\hline
\end{tabular}

\section{Source: Direct Search}

\section{CONCLUSIONS}

The most prevalent form of depression in the elderly is depression of increasing severity. It most commonly affects individuals aged 80 or over. Suicidal ideation was little identified in the study population. The idea of death being more related to the female sex.

\section{REFERECE}

1. AGUIAR, Marcelo. Por que algumas pessoas sofrem de depressão? Belo Horizonte: Betânia, 2004.

2. ALMEIDA O.P.; ALMEIDA, S.A. Confiabilidade da versão brasileira da Escala de Depressão Geriátrica (GDS) versão reduzida. Arq Neuropsiquiatr. v.57, n.2B, p.421-426, 1999.

3. ANDRADE, A. C. A. et al. Depressão em idosos de uma instituição de longa permanência (ILP): proposta de ação de Enfermagem. Revista Gaúcha Enfermagem. Porto Alegre (RS) 2005.

4. BAGHERI-NESAMI, M.; RAFII, F.; OSKOUIE, S. F. H. Coping strategies of Iranian elderly women: A qualitative study. Educational Gerontology, v.36, p.573-591, 2010.

5. BARROSO, V. L.; TAPADINHAS, A. R. (2006). Orfãos de solidão e depressividade face ao envelhecimento - estudo comparative entre idosos institucionalizados e não institucionalizados. Retirado em 3, Novembro, 2010, de www.psicologia.com.pt.
6. BARUA, A.; KAR, N. Screening for depression in elderly Indian population. Indian Journal of Psychiatry, v.52, p.150-153, 2010.

7. BECK, A T., RUSH A J., SHAW, B. F. \& EMERY, G. Terapia cognitiva da depressão. Porto Alegre, Artes Médicas, 1997.

8. BRASIL, Ministério da Saúde. Secretaria de Atenção à Saúde. Departamento de Atenção Básica. Envelhecimento e saúde da pessoa idosa, Brasília: Ministério da Saúde, 2007.

9. BREZO, J.; BARKER, E.D.; PARIS J, HÉBERT M, VITARO F, TREMBLAY RE, TURECKI G. Childhood trajectories of anxiousness and disruptiveness as predictors of suicide attempts. Arch Pediatr Adolesc Med. 2008; v.162 n.11, p.1015-1021, 2008.

10. BLACKMORE, E.R.; et al. Psychosocial and clinical correlates of suicidal acts: results from a national population survey. Br J Psychiatry.,v.192, n. 4, p.279-84, 2008.

11. CAMARANO AA et al. Idosos Brasileiros: indicadores de condições de vida e de acompanhamento de políticas. Brasília: Presidência da República, Subsecretaria de Direitos Humanos, 2005.

12. CARREIRA, L.; BOTELHO, M.R.; MATOS, P.C.B. ; TORRES,M.M.; SALCI, M.A. Prevalência De Depressão em Idosos Institucionalizados. Revista de Enfermagem, v. 19, n. 2, p. 268-73, 2011. 
13. CARVALHO FILHO, Eurico Thomaz; PAPALÉO NETTO, Mateus. Geriatria: fundamentos clínica e terapêutica. 2. ed. São Paulo: Atheneu, 2005.

14. CHAIMOWICZ, F.; GRECO, D.B. Dinâmica da institucionalização de idosos em Belo Horizonte. Rev Saúde Pública. v.33, n.5, p.454-60, 1999.

15. CONWELL Y, THOMPSON C. Suicidal Behavior in Elders. Psychiatr Clin North Am., v.31, n.2, p.333-356, 2008.

16. CORDIOLI, A. V. et al. Psicoterapias: abordagens atuais. 3 ed. Porto Alegre: Artmed, 2008.

17. DALGALARRONDO, Paulo. Psicopatologia e semiologia dos transtornos mentais. 2. ed. São Paulo: Artmed, 2008.

18. DRAGO, S. M. M. S.; MARTINS, R. M. L. A depressão no idoso. Millenium - Revista do IPV, n.43, p. 79-94, jun.-dez. 2012.

19. DENIHAN, A., et al. Three-year prognosis of depression in the community-dwelling elderly. British Journal of Psychiatriy, v.176, p.453-457, 2000.

20. DE LEO D. et al. Attempted and completed suicide in older subjects: results from the WHO/EURO Multicentre study of suicidal behaviour. Int J Geriatr Psychiatr. 2001;16(3):300-10. DOI:10.1002/gps.337

21. ELIOPOULOS, Charlotte. Enfermagem gerontológica. 5. ed. Porto Alegre:Artmed, 2005.

22. FORSELL Y. Predictors for depression, anxiety and psychotic symptoms in a very elderly population: data from a 3-year follow-up study. Soc Psychiatry Psychiatr Epidemiol. 2000, v.35, p.259-263.

23. IBGE, INSTITUTO BRASILEIRO DE GEOGRAFIA E ESTATÍSTICA, Síntese de Indicadores Sociais a partir da Pesquisa Nacional por Amostra de Domicílios de 2010 e do Censo de

2010

http://biblioteca.ibge.gov.br/visualizacao/periodic os/

93/cd_2010_caracteristicas_populacao_domicilio s.pdf, ISSN 0104-3145, Rio de Janeiro, 2011.

24. IBGE, INSTITUTO BRASILEIRO DE GEOGRAFIA E ESTATÍSTICA, Síntese de Indicadores Sociais a partir da Pesquisa Nacional por Amostra de Domicílios de 2014 e do Censo de 2014, http://biblioteca.ibge.gov.br/idosos. Rio de Janeiro, 2014.

25. LEITE, V.M.M.; CARVALHO, E.M. F.; BARRETO, K. M. L.; FALCÃO, I.V. Depressão E Envelhecimento: Estudo Nos Participantes Do Programa Universidade Aberta À Terceira Idade. Revista Brasileira Saúde Materno Infantil, v. 6, n. 1, p.31-8, 2006.

26. MANRIQUE-ESPINOZA, B et al. Prevalencia de dependência funcional y su asociación com caídas en una muestra de adultos mayores pobres en México. Salud Pública de México, v.1, n.26-33, 2011.

27. McGIRR A.; et al. An examination of DSM-IV depressive symptoms and risk for suicide completion in major depressive disorder: a psychological autopsy study. J Affect Disord. v.97, n.1-3, p.203-9, 2007.

28. McGIRR A.; et al. Risk factors for suicide completion in borderline personality disorder: a case-control study of cluster B comorbidity and impulsive aggression. J Clin Psychiatry., v.68, n.5, p.721-9, 2007.

29. McINTYRE, A.; ATWAL, A. Terapia ocupacional e a terceira idade. São Paulo: Santos, 2007.

30. MCKENZIE, Kwame. Depressão. São Paulo: Três. (Coleção Guia da Saúde Familiar, 7).Miller, M. C. (2009). Treating generalized anxiety disorder in the elderly. Harvard Mental Health Letter, v.3, p.1-4, 2008.

31. MIGUEL JÚNIOR, Armando. Depressão presente na vida do idoso. Medicina Geriátrica. Disponível em:

<http://www.medicinageriatrica.com.br/2007/10/0 4/depressao-presente-na-vida-do-idoso/>.

Acesso em: 23 mar . 2015.

32. MITTY E; FLORES S. Suicide in Late Life. Geriatr Nurs., v.29, n.3,p.160-165, 2008.

33. MOREIRA, A. S. P. et al. Perspectivas teóricometodológicas em representações sociais. João Pessoa: UFPB, 2005.

34. NGUYEN H.T.; ZONDERMAN A.B. Relationship between age and aspects of depression: consistency and reliability across two longitudinal studies. Psychol Aging. 2006;21:119-26

35. OLIVER, A. et al. Modelo de ecuaciones estructurales para predecir el bienestar y la dependencia functional en adultos mayors de la república dominicana. Revista Panamericana de Salud Pública, v.3, p.189-196, 2009.

36. PAPALIA, D. E., \& OLDS, S. W. Desenvolvimento físico e cognitiva na terceira idade. In: D. E. PAPALIA \& S. W. OLDS. Desenvolvimento humano, Artes Médicas, Porto Alegre, p.491-521, 2000.

37. PAPALÉO NETTO, Mateus. Tratado de gerontologia. 2. ed. São Paulo: Atheneu, 2007.

38. PÓVOA, T. R.; et al. Prevalência de depressão em idosos institucionalizados na morada do idoso do instituto de gerontologia de Brasília. Revista Brasília Médica. Brasília, v. 46, n. 3, p. 241-246, 2009.

39. RIBEIRO, K. C. S. et al. Representações sociais da depressão no contexto escolar. São Paulo: Paidéia, 2007. 
40. ROTHERMUND, K.; BRANDTSTADTER, J. Depression in later life: crosssequential patterns and possible determinants. Psychol Aging.2003;18:80-90.

41. RYAN J, CARRIERE I, RITCHIE K, STEWART R, TOULEMONDE G, DARTIGUES J, TZOUURIO $C$, ANCELIN M. Late-life depression and mortality: influence of gender and antidepressant use. Br J Psychiatry, v.192, p.12-18, 2008.

42. SADOCK, B. J.; SADOCK, V. A. Compêndio de psiquiatria: ciência do comportamento e psiquiatria clínica (9a ed.). Porto Alegre: Artmed, 2007.

43. SANTOS, M. et al. The impact of vascular burden on late-life depression. Brain Researchs Reviews, v. 62, n. 11, p.19-32, 2009.

44. SANTOS, J.G.; PEREIRA, J.R.; TEIXEIRA, C.V.L.;CORAZZA,D..I; VITAL,T.M.;COSTA,J.L.R. Sintomas depressivos e prejuízo funcional de idosos de um Centro- Dia Geriátrico. Revista Brasileira de Psiquiatria, v. 61, n.2, p.102-6, 2012.

45. SHAH A, BHAT R. Are elderly suicide rates improved by increased provision of mental health service resources? A cross-national study. Int Psychogeriatr v.20, n.6, p.1230-1237, 2008.

46. SHAH, A.; SUH, G. H. Elderly suicides in Korea: time trends and age-associated trends. Journal of Chinese Clinical Medicine, v.5, p.274-281, 2009.

47. SIQUEIRA, G. R.; et al. Análise da sintomatologia depressiva nos moradores do Abrigo Cristo Redentor através da aplicação da Escala de Depressão Geriátrica (EDG). Revista Ciência e Saúde Coletiva. Rio de Janeiro, v. 14, n. 001, p. 253-259, 2009.

48. SINOFF, G; WERNER, P. Anxiety disorder and accompanying subjective memory loss in the elderly as a predictor of future cognitive decline. International Journal of Geriatric Psychiatry, v. 18, p.951-959, 2003.

49. STUART, Gail W. ; LARAIA, Michele T. Enfermagem Psiquiátrica: princípios eprática. 6. ed. Porto Alegre: Artmed, 2001.

50. TIER, G. C.; FONTANA, T. R.; SOARES, V.N. Refletindo sobre os idosos institucionalizados. Revista Brasileira, v.57, n.3, p.332-335, 2004.

51. TIER, C. G; LUNARDI, V. L. L; SANTOS, S. S. C. Cuidado ao idoso deprimido e institucionalizado à luz da Complexidade. Revista Eletrônica de Enfermagem , v.10, n.2, p.530-536, 2008.

52. TOWNSEND, Mary C. Enfermagem psiquiátrica: conceitos e cuidados. 3. ed.

53. Rio de Janeiro. Guanabara Koogan, 2002.

54. WANG, P. S. et al. (2008). The impact of cost sharing on antidepressant use among older adults in British Columbia. Psychiatric Services, v.4, p.377-383, 2008. 